\section{Livermore plans ignite protests over nuclear weapons}

Geoff Brumfiel, Washington

Nuclear watchdogs and former weapons scientists are taking issue with a proposal to use weapons-grade uranium and plutonium at the US National Ignition Facility. The facility is supposed to help scientists assess the nation's ageing nuclear stockpile without testing the weapons themselves, but there are fears that it could now be used to design new warheads.

Opponents of new weapons were preparing to denounce the plan at public hearings this week in Washington and at the Lawrence Livermore National Laboratory in California, where the facility is located. They say that the proposal will speed the development of 'mini-nukes', which have been promoted by the Bush administration (see Nature 415, 945; 2002). "Such experiments link directly to new, low-yield weapons," warns Ray Kidder, a retired weapons physicist who was based at the Livermore laboratory.

Livermore officials deny that the research will be used to design new weapons. Instead, says laboratory spokeswoman Lynda Seaver, it will investigate how existing bombs detonate, so that the stockpile can be maintained without testing the weapons it contains.

The National Ignition Facility uses 192 high-power lasers to fuse hydrogen isotopes together, releasing energy. But part of its environmental-impact statement, released in February, announced plans to line the hydrogen fuel pellets with fissile materials, which would split apart under the laser light. The statement says that this is necessary "to accurately evaluate the properties of nuclear material in the laboratory and to validate weapons test data".

Kidder and other critics question this claim. The move would allow researchers to optimize designs for low-yield nuclear weapons, he says. A 1995 Livermore panel on which he sat warned that such work might be seen as provocative by other nations, Kidder adds.

The environmental-impact statement also proposes doubling the amount of plutonium held at the laboratory and restarting a plutonium enrichment programme. "This work is going in the wrong direction," warns Loulena Miles, a lawyer at Tri-Valley CAREs, an antinuclear weapons group based next to Livermore. "It is moving the laboratory towards weapons manufacturing." But Seaver says that the statement is "only a proposal" for future activities at the lab.

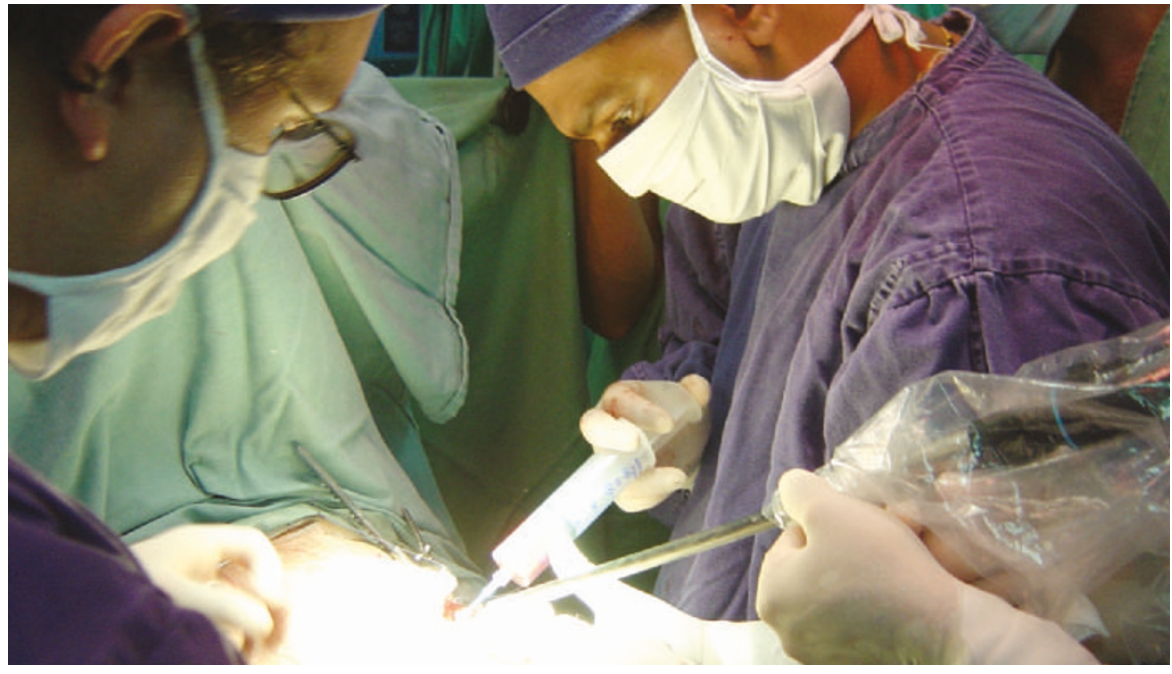

Muscling in: stem cells are injected into a patient's heart during bypass surgery.

\title{
Cardiologists take heart from stem-cell treatment success
}

\section{Erika Check, Washington}

The prospects for using adult stem cells in medical treatments improved this week, when cardiac surgeons reported that injecting bone-marrow cells into the heart can boost its function.

The finding, released on 25 April at the annual meeting of the American Association for Thoracic Surgery in Toronto, Canada, is set to add heat to an ongoing debate about whether such therapies have benefits that outweigh their risks.

The study looked at 20 people with heart failure and is the largest clinical trial so far to include stem-cell treatment. The hearts of ten patients were injected with stem cells purified from their bone marrow during bypass surgery. The other ten underwent bypass surgery but did not receive any stem cells, says Amit Patel of the University of Pittsburgh School of Medicine in Pennsylvania, the principal investigator.

Six months after surgery, the patients' heart function was assessed by checking the amount of blood pumped with each beat. The score on this scale for those who received stem cells was almost ten points higher than for those who only had the bypass.

Stem cells from bone marrow are classified as 'adult' and their use is less politically fraught than that of embryonic stem cells. Adult stem cells have long been viewed as less flexible than embryonic stem cells, which can divide to produce any cell type in the body. But recent studies of human cells suggest that adult stem cells can also turn into many cell types, including heart, brain and liver cells. Supporters of adult stem-cell therapies say that this is what probably happened in Patel's trial — but not everyone agrees.

"This clinical trial basically says that bone-marrow cells do differentiate" into heart muscle, says cardiologist Piero Anversa of the New York Medical College in Valhalla, New York, who has reported the same finding in mice ${ }^{1}$.

But critics say that when scientists use genetic markers to track bone-marrow cells injected into mouse hearts, the cells do not change type ${ }^{2,3}$. They speculate that other mechanisms, such as the effects of chemicals used in the bone-marrow preparation, could explain the improvement in heart function.

"I'm a little sceptical about the result because it is a verylimited study, and so far the evidence for the regenerating effect of bone marrow is very controversial," says cardiac surgeon Philippe Menasche of the Georges Pompidou European Hospital in Paris.

Patel admits that it is not clear whether the bone-marrow cells actually changed type. He adds that his group will soon begin a follow-up study to examine this question in humans. Patients who are to undergo a heart transplant will have their hearts injected with bone-marrow cells months before their operation. Then, when they undergo surgery, the team will dissect and examine the old hearts to see whether the bonemarrow cells did indeed change type.

Many scientists say that they are reluctant to undertake further large clinical trials of the technique until they hear more definitive answers about the risks and benefits of adult stem-cell therapies.

"I'm not trying to downplay the fact that they've seen a benefit," says developmental biologist Jonathan Epstein of the University of Pennsylvania in Philadelphia. "But there's a risk to implanting cells into the heart, and if the benefit is unrelated to the regeneration of cells then we might be able to develop a therapy that has fewer risks."

\footnotetext{
. Orlic, D. et al. Nature 410, 701-705 (2001).

. Murry, C. E. et al. Nature 428, 664-668 (2004)

Balsam, L. B. et al. Nature 428, 668-673 (2004)
} 